When planted with other trees it stands out conspicuously; but probably, to appreciate its beauty to the full it should be seen as so many famous artists loved to paint it, in a group standing on high ground, thus outlined against the sky.

Under good conditions the Scots pine grows with great rapidity, reaching a height of about $100 \mathrm{ft}$., a clean bole of $70-80 \mathrm{ft}$., with a girth of 10-11 ft.

The bark is tough and fissured; the lower part of a dark reddish-brown, and the upper smoother and bright red. In early life the thick bushy foliage grows in pyramidal form flattening out later into tiers of irregular shape.

Johns tells us that in the Highlands of Scotland

"almost every district bears the trace of the vast forest with which at no very distant period, the hills and heaths were covered... on the South of Ben Nevis a large Pine forest . . . was burned to expel the wolves."

One wonders whether Robert Bridges had made a study of scientific forestry when he wrote:

"His spear, to equal which the tallest pine hewn on Norwegian hills . . . were but a wand."

However that may be, it is a fact that in Norway, Sweden, Finland and Russia the Scots pine has played the most important part in the economic history of these countries; especially in Russia has the subject received intense study, and been given every scientific assistance, but unfortunately the same cannot be said of Great Britain, with the exception of some effort since the establishment of the Forestry Commission.

It is not surprising, therefore, that the quality of British-grown pine has been found generally very inferior to that imported from these other countries. Whereas in the U.S.S.R. an excellent system of grading has been adopted, in most other places, either little attention has been paid to the question, or conditions do not allow of much variation, for the general quality of the timber is fairly uniform, and up to now could not be classed in a high grade. The variation in England, however, is considerable, some districts producing excellent timber while others only poor quality.

Lord Sackville told me that one of his ancestors three hundred years ago brought from Memel Scots pine planks to provide floors for the long galleries at Knowle Park, Sevenoaks, as the trees growing on his own land, though abundant, were of poor quality.

In the time of Samuel Pepys, Scots pine was only imported in one dimension - three inches by nine inches and $12 \mathrm{ft}$. in length. These were termed 'deals' in England; other sizes were termed 'planks', 'battens' and 'scantlings'. Curiously enough, whereas the other terms were never adopted except for their real meaning, the word 'deal' became known to describe any kind of coniferous wood regardless of size, the name being still used wherever English is spoken.

Samuel Pepys, under date of October 18, 1664, records in his Diary :

"Thence to the Exchange, and so home to dinner, and then to my office, where a full board, and busy all the afternoon, and among other things made a great contract with Sir W. Warren for 40,000 deals Swinsound, at $£ 3.17 /$ - per hundred."

One hundred deals of similar character would cost to-day $£ 69$ 17s. Swinsound was a port of Norway, about a mile from Fredrikshald, close to Frederikstadt, and now called Halden. The deals were handsawn and of superior quality. Norwegian imports, under the name of 'Christiania', continued, and the name 'Christiania deals' was still in use up to 1939 . Probably the last shipment into England was in 1878, after which Norwegian supplies failed. From this time forward importations from Sweden, Finland and Russia increased in volume year by year; later supplies were received from Canada, America, southern Europe and Poland. All these revealed an ever-growing destruction of the larger trees. For several years after 1878 shipments consisted of more than 75 per cent of sizes 3 in. by 9 in. and larger, with only 25 per cent of smaller dimensions, but by the year 1939, except for the U.S.S.R., only 15-20 per cent could be obtained of the larger sizes. While with the Russian a better average of large sizes was maintained, not more than one piece in five was free of the centre, whereas in earlier years only one centre piece would be found with four or five quite free. Throughout, the inclusion of sap wood has greatly increased, and scantling sizes are almost all sap wood. The foregoing is a clear indication of the manner in which the forests are being exhausted.

In $1937-38$ we expended the immense sum of $£ 51$ million on importations from Sweden, Norway, Finland, the U.S.S.R., Esthonia, Latvia, Lithuania, Poland, Yugoslavia and Rumania, the principal of which was Scots pine. This was used for joists, beams, rafters, flooring, etc., and the better qualities for joinery work, doors, window-frames, shelves and cupboards, etc. Prior to this War (1939) trees grown in Great Britain were used only for rough work such as gates and fences, and for estate purposes, but lately so great has been the demand that what was once considered inferior is now regarded of great value. Bearing in mind the vast building operations which will be necessary for many years after the War, Scots pine will be more than ever in demand, and should be planted freely in all suitable areas where the climate and soil are congenial, and reared on the most scientific principles of forestry, in order that the quality may be improved.

\section{PRINCIPLE AND PRACTICE IN VEGETATIVE PROPAGATION}

$\mathrm{P}$ RACTICES of vegetative propagation of plants, originated in antiquity, and used without change for many centuries, have probably received a greater. inspiration from modern science than any other ofman's ancient occupations. The discovery of plant hormones made it possible to propagate species which had previously defied the greatest horticultural skill. There are, however, many other factors which have recently been passed in masterly review by $\mathrm{R}$. J. Garner*.

Although the title of the pamphlet places special emphasis on pome and stone fruits, the work includes consideration of a wide variety of plant species, and certain generalizations are possible. New growth is a better source of cuttings than older material, and the presence of abundant stored carbohydrate food also assists this form of propagation. Indeed, soaking cuttings in sugar solution has often induced rooting. Lateral shoots are superior to terminals, and basal

* lmp. Bur. of Hort. and Plantation Crops. (Tech. Comm. No. 14.) Pp.1-79. (I.A.B. Central Sales Branch, Agricultural Research Building, Penglais, A berystwyth, Jan. 1944.) 3 s. 6d. net. 
cuttings root best. "The time of taking cuttings should be governed by the condition of the material rather than by the calendar." Various methods of application of synthetic hormone substances are described and, although these still give varying results, they represent by far the greatest single advance in technique. The effects of temperature, moisture and light form an interrelated complex, which should be determined for each species. Wound stimulation can increase rooting response; leaves are generally necessary, but flowers are a hindrance to regeneration.

Rooting media must be well aerated, but must also hold sufficient moisture; peat is considered to provide rooting stimulants, possibly of hormone nature. Some stem cuttings root better after an initial period of inversion, while some root cuttings regenerate better if the proximal end is above the compost. The presence of nitrogen hinders the rooting of normal plants, but nitrogen-starved growth may occasionally be stimulated to root by treatment with suitable nutrient solutions. Layering and marcotting (aerial layering) appear to depend for their full success upon some form of constriction or ringing which presumably increases the carbohydrate in the parts which are to root. Mr. Garner finally discusses the application of principles revealed by his survey to the practices of propagating fruit trees in use at the East Malling Research Station. Many orchards and nurseries are at present in bad condition because of the War, and Mr. Garner's publication has the objective aim of demonstrating the best methods for their restoration when peace returns.

\section{GROWTH OF CEREAL EMBRYOS}

GINCE the pericarp in a cereal such as barley is $N$ semi-permeable, during the first period of germination the embryo is exposed to a low level of water and oxygen availability $(0 \cdot 1$ atm. $)$ and a relatively high carbon dioxide concentration (0.1 atm.) (R. Brown, Ann. Bot., N.S., 93 and 275 ; 1943). In contrast, when excised embryos are being cultured, as in attempts to elucidate some of the problems of vernalization and kindred phenomena, the young plants are being started under conditions of high water and oxygen availability. Whether grown on water or culture solutions, such isolated embryos always show an immediate drop in dry weight, followed by a slower loss over at least the first twelve hours, suggesting a leaching effect followed by a rather higher rate of respiration than in the embryos of intact grains.

The change-over from a dormant embryo with dense non-vacuolate cells to a seedling in a fully active state seems to occupy about the first seventytwo hours, since after that time the water content remains constant. Although the food reserves in the endosperm are not available to the young plant during the first twenty-four hours of germination, excision within the first twelve hours of germination affects the linear and dry-weight growth, suggesting either that some substance is being absorbed (a hormone?) or that the internal carbon dioxide concentration has a stimulating effect, either directly or by altering the acidity of the environment. When the carbon dioxide concentration is high, as in an intact grain, a low level of water-availability stimulates the linear and dry-weight growth of the embryo, either when attached or when growing on a nutritive medium. On the other hand, linear and dry-weight growth do not appear to be influenced by changes in oxygen concentration provided it is above about 15 per cent.

"Each of the factors considered above tends to be at a level inside the seed which, relative to the incident level of the same factor outside the seed, stimulates the subsequent growth of the seedling"; and there is probably "a high degree of instability in the metabolic pattern of the embryo . . subject to modification according to the nature of the environment in which early development occurs".

\section{FORTHCOMING EVENTS}

(Meeting marked with an asterisk: * is open to the public)

\section{Saturday, November 25}

AsSOCIATION For SCIENTIFIC PHotography (joint meeting with the Sctentific and Technical group of the Royal Photographic SocIETX) (at 16 Princes Gate, South Kensington, London, S.W.7), at 3 p.m.-Mr. G. Parr: "The Electron Microscope": Dr. E. M. Crook, Miss F. M. L. Sheffeld and Mr. L. V. Chilton: "Photographic "Electron Micrography of Textiles".

\section{Monday, November 27}

Royal Society of ARTs (at John Adam Street, Adelphi, London, ROYAL SOCIETY OF ARTS (at John Adam "Milk"et, Ad "The Hormonal W.C.2), at 1.45 p.m.--Dr. S. J. Folley: "D.
Control of Lactation" (Cantor Lecture).

ROXAL GEOGRAPHICAL SOCIETY (at Kensington Gore, South Kensington, London, S.W.7), at 5 p.m.-Mr. C..Hope Gill: "The Hadhramaut" (Kodachrome Film).

BRITISH INSTITUTION OF RADTO ENGINEERS (LONDON SECTION) (at the Institution of Structural Engineers, 11 Upper Belgrave Street, hondon, S.W.1), at $6 \mathrm{p}, \mathrm{m}$ - Mr. E. R. Friedlander: "Magnetic Dust Cores".

INSTITUTYON OF ELECTRICAL ENGINEERS (LONDON STUDENTS' SECrIoN) (at Savoy Place, Victoria Embankment, London, W.C.2), at 7 p.m.-Mr. W. A. Hatch: "Some Hydro-Electric Possibilities and Achievements".

IRON AND STEEL INSTITUTE (joint meeting with the SHEFFIELD BRANCH OF THE INSTITUTE OF BRITISH FOUNDRYMEN) (at the Roya Victoria Hotel, Sheffield), at 7 p.m.-Mr. B. Gray: "The Side Feeding of Steel Castings - a Note on the Influence of the Mechanism of Freezing".

\section{Tuesday, November 28}

British Psychological Societry (Industrial Section) (at the National Institute of Industrial Psychology, Aldwych "House, Aldwych, London, W.C.2), at 12.45 p.m. -Prof. E. A. Bott: "Some Problems of Selection and 'Training in War and in Peace" (followed by Questions

ROX AL ANTHROPOLOGICAL INSTITUTE (at the Royal Society, Burlington House, Piccadilly, London, W.1), at 1.30 p.m.-Prof. V. Gordon Childe: "Archæological Ages as Technological Stages" (Huxley Memorial Lecture).

Institotion of BrTtish Agrtcultural Engineers (at the Institution of Electrical Engineers, Savoy Place, Victoria Embankment, London, W.C.2), at 2 p.m.-Mr. C. Culpin: "Machinery for Crop Cultivation".

CHADWICK LECTURE (at the Sir Edward Meverstein Lecture Theatre, Westminster Hospital Medical School, 17 Horseferry Road, WestWestminster Hospital Medical school, 17 Horserery Hoad, Wrincker minster, London, S.W.1), at 2.30 p.m.-Mr. J. A. H. Brincker "Research in all its Various Aspects Essential corm Morris Memorial Health and ${ }^{*}$

RoYal Institurtion (at 21 Albemarle Street, Piccadilly, London, WOY 15.15 p. Diseases", (ii) "The Properties of Purified Plant Viruses".

ROYAL STATISTICAL SOciety (at the Royal Society of Arts, John Adam Street, Adelphi, London, W.C.2), at 5.15 p.m.-Sir William Elderton: "C'ricket Scores and Some Skew Correlation Distributions (An Arithmetical Study)": Mr. George H. Wood: "Cricket Scores and Geometrical Progression".

Institute of Petrolkum (at 26 Portland Place, London, W.1), at 5.30 p.m. - Reception to the Visiting Indian Scientists, when addresses will be

Institution of Civit ENGineers (at Great George Street, Westminster, London, S.W.1), at 5.30 p.m.-Mr. A. Shaw Maclaren: "The Design of Land Airports for Medium and Long Distance Civil Air Transport",

NORTH-EAST COAST INSTITUTION OF ENGINEERS AND SHIPBCILDERS, (in the Lecture Theatre of the Mining Institute, Newcastle-upon-Tyne) at $6 \mathrm{pm}-\mathrm{Mr}$. E. Leslie Champness: "University Education in Shipbuilding and Naval Architecture".

SheFrield Metallurgicai Association (at 198 West Street, SHEFTIELD METALLURGICAI ASSOCIATION (at 198 West Street Banded Structures in Centrifugal Casting". 